ISSN (Print) : 1412-7601

ISSN (Online) : 2654-8712

Volume 4, No.2 September 2018

EKONOBIS

http://www.ekonobis.unram.ac.id

\title{
Pengaruh Variabel Ekonomi Dan Sosial Terhadap Penyerapan Tenaga Kerja Di Provinsi Nusa Tenggara Barat
}

\section{Wahidin, Sataruddin.}

Universitas Mataram

\begin{tabular}{l}
\hline A R T I C LE I N F O \\
\hline Keywords : \\
employment, money \\
supply, government \\
spending, the level of \\
minimum wages, \\
investment, and education.
\end{tabular}

Kata Kunci :

penyerapan tenaga kerja, jumlah uang beredar, belanja pemerintah daerah, tingkat upah kabupaten, investasi, dan pendidikan.
Received : 4 Juli 2018; Accepted: 2 Agustus 2018; Published: September 2018

ABSTRACT : The purpose of this study to analyze the effect of economic variables and social variables on employment. Economic variables: the amount of money in circulation, local government spending, wages district, investment. Social variables: education. Using time series and cross-section data years 2013 - 2015 from 10 districts and cities. Data analysis using OLS (Ordinary Least Square) to process the data panel. The independent variable: the money supply (X1), local government expenditures (X2), the wage rate districts and cities (X3), investments (X4), education (X5) and the dependent variable is employment $(Y)$. The results showed: the money supply $(X 1)$ and investments (X4) no significant effect on employment, while spending on local government districts and cities (X2), the wage rate districts and cities (X3), and education (X5) effect significantly to employment.

ABSTRAK : Tujuan penelitian ini untuk menganalisis pengaruh variabel ekonomi dan variabel sosial terhadap penyerapan tenaga kerja. Variabel ekonomi: jumlah uang beredar, belanja pemerintah daerah, tingkat upah kabupaten, investasi. Variabel sosial: pendidikan. Menggunakan data runtut waktu (time series) dan data (cross-section) tahun 2013 - 2015 dari 10 kabupaten dan kota. Analisis data menggunakan metode OLS (Ordinary Least Square) untuk proses panel data. Variabel independen: jumlah uang beredar $\left(X_{1}\right)$, belanja pemerintah daerah $\left(X_{2}\right)$, tingkat upah minimum kabupaten dan kota $\left(X_{3}\right)$, investasi $\left(X_{4}\right)$, pendidikan $\left(X_{5}\right)$ dan variabel dependen adalah penyerapan tenaga kerja $(Y)$. Hasil penelitian menunjukkan: jumlah uang beredar $\left(X_{1}\right)$ tidak berpengaruh secara signifikan terhadap penyerapan tenaga kerja. Demikian juga investasi $\left(X_{4}\right)$ tidak berpengaruh secara signifikan terhadap penyerapan tenaga kerja. Belanja pemerintah daerah kabupaten dan kota $\left(X_{2}\right)$, tingkat upah minimum kabupaten dan kota $\left(X_{3}\right)$, dan pendidikan $\left(X_{5}\right)$ berpengaruh secara signifikan terhadap penyerapan tenaga kerja.

Corresponding Author :

Alamat : Program Studi Ekonomi Pembangunan, Fakultas Ekonomi dan Bisnis, Universitas Mataram, Jln. Majapahit No. 62 Mataram.

e-mail:wahidin@unram.ac.id 


\section{PENDAHULUAN}

\section{Latar Belakang}

Pembangunan wilayah merupakan proses Pembangunan yang dilaksanakan dari tahun ke tahun oleh pemerintah dan masyarakat dalam bidang ekonomi dan dalam bidang non ekonomi bertujuan untuk meningkatkan output nasional dan kesempatan kerja. Dengan terjadinya peningkatan output nasional dan kesempatan kerja diyakini akan meningkatkan kesejahteraan masyarakat sebagai wujud dari amanat Undang-undang Dasar 1945 pasal 27 ayat 2 yang berbunyi “ Tiap-tiap warga Negara berhak atas pekerjaan dan penghidupan yang layak bagi kemanusiaan".

Keberhasilan pembangunan dapat diiukur dari indikator prestasi makroekonomi suatu Negara/daerah. Prestasi makro ekonomi suatu Negara dalam perekonomian tertutup yaitu: 1) output nasional yang semakin tinggi atau laju pertumbuhan ekonomi yang mengalami pertambahan yang semakin pesat; 2) kesempatan kerja yang semakin luas atau tingkat pengangguran semakin rendah; dan 3) tingkat inflasi yang rendah. Jika ke tiga indikator ini terwujud maka perekonomian suatu Negara/daerah dapat dikatakan mengalami kemajuan pembangunan ekonomi.Sebaliknya, jika ke tiga indikator ini belum terwujud maka perekonomian suatu Negara/daerah dapat dikatakan belum mengalami kemajuan pembangunan ekonomi.

Salah satu indikator keberhasilan pembangunan ekonomi Negara/daerah tersebut di atas adalah kesempatan kerja yang semakin luas atau tingkat pengangguran yang semakin turun dari tahun ke tahun. Secara nasional tingkat pengangguran terbuka (TPT) mengalami penurunan dari, tahun ke tahun dalam data lima tahun terakhir. Tahun 2010 (7,14\%), tahun 2012 (6,13\%) dan tahun 2014 sebesar 5,94 \% (BPS: tenaga kerja, 2015). Berdasarkan data ketenagakerjaan ini maka dapat dikatakan bahwa secara nasional mengalami kemajuan pembangunan ekonomi dalam lima tahu terakhir.

Berdasarkan

indikator ketenagakerjaan (tingkat pengangguran terbuka) ini, dalam lima tahun terakhir ini pembangunan ekonomi Propinsi Nusa
Tenggara Barat belum mengalami kemajuan yang berarti. Tingkat pengangguran mengalami peningkatan dari tahun ke tahun. Atau dengan kata lain, tingkat kesempatan kerja mengalami penurunan dari tahun ke tahun. Tahun 2010 tingkat pengangguran sebesar 5,29\%, naik menjadi 5,38 \% tahun 2013, dan naik lagi menjadi 5,75 \% tahun 2014 (BPS: Ketenagakerjaan tahun 2015). Ini berarti kesempatan kerja turun, dari 94,71\% turun menjadi 94,25\% tahun 2014. Kalau dibandingkan secara nasional, tingkat pengangguran di propinsi NTB masih di bawah tingkat pengangguran nasional.Tetapin arahnya berbeda, secara nasional mengalami penurunan sedangkan tingkat pengangguran propinsi NTB mengalami peningkatan.

Saat ini, persoalan pokok yang dihadapi dalam bidang ketenagakerjaan adalah kelebihan tenaga kerja serta sempitnya kesempatan kerja yang tercipta pada setiap sektor sehingga terjadi pengangguran.Selain terjadi ketidakseimbangan antara percepatan pertambahan jumlah angkatan kerja dengan pergerakan kesempatan kerja, ternyata karena perkembangan teknologi prasyarat yang dibutuhkan kesempatan lapangan kerja baru tidak dipenuhi pencari kerja.Artinya, kualitas pengangguran tidak dapat memenuhi prasyarat lowongan yang ada. Pengangguran jika tidak dikelola secara baik akan merupakan pemborosan yang menjadi beban masyarakat. Namun disisi yang lain jika dikelola secara tepat, pengangguran dapat menjadi tenaga profesional yang produktif dan menjadi asset bangsa yang sangat tinggi nilainya.

Pengangguran angkatan kerja di propinsi Nusa Tenggara Barat masih mencapai angka yang cukup besar. Tahun 2013 tingkat pengangguran sebesar $5,38 \%$ dari total angkatan kerja 2,094 juta orang. Sedangkan penyerapan angkatan kerja sudah mencapai 1,981 juta orang $(94,62 \%)$ (BPS, 2014). Tahun 2015, pengangguran terbuka meningkat menjadi 5,69 \% atau sebesar 128.376 orang dari total angkatan kerja sebesar 2.255.879 orang. Sedangkan penyerapan tenaga kerja sebesar 2.127.503 orang atau sebesar 94,31 $\%$. Dari 94,31 \% ini, sektor pertanian menyerap sebesar $36,79 \%$, industri pengolahan sebesar $8,84 \%$, perdagangan, 
hotel dan restoran sebesar 20,35 \%; dan sektor jasa-jasa sebesar 15,53 \% (BPS: Propinsi Nusa Tenggara Barat Dalam Angka 2016).

Secara teoritis bahwa variabel ekonomi dan variabel sosial sangat menentukan tingkat penyerapan tenaga kerja. Variabel ekonomi yang mempengaruhi tingkat penyerapan tenaga kerja adalah jumlah uang beredar, dana investasi, Tingkat upah, Produk domestik Regional Bruto (PDRB), nilai produksi, dan anggaran pendapatan dan belanja daerah (APBD). Sedangkan variabel social yang mempengaruhi penyerapan tenaga kerja adalah tingkat pendidikan. Masing-masing variabel ekonomi dan variabel sosial ini secara teoritis mempunyai pengaruh terhadap penyerapan tenaga kerja .Tetapi besarnya pengaruh dan tingkat kesignifikasinya masing-masing variable belum dapat diketahui.Angka besarnya pengaruh dan tingkat signifikasi masingmasing variable sangat penting untuk diketahui sebagai dasar untuk menentukan kebijakan yang harus diambil dalam rangka mempertinggi tingkat penyerapan tenaga kerja di propinsi NTB.

Untuk mengetahui besarnya pengaruh dan tingkat signifikasi masingmasing variable ekonomi dan variabel sosial terhadap penyerapan tenaga kerja maka perlu dilakukan suatu penelitian. Karena itu maka penelitian ini dilakukan dengan judul: Pengaruh Variabel Ekonomi Dan Variabel Sosial Terhadap Penyerapan Tenaga Kerja Di Propinsi Nusa Tenggara Barat.

\section{Perumusan Masalah}

Berdasarkan uraian pada latar belakang di atas maka dapat dirumuskan masalah penelitian adalah "Apakah variabel-variabel ekonomi dan variabel sosial berpengaruh secara signifikan terhadap penyerapan tenaga kerja".

\section{Tujuan Penelitian}

Penelitian ini bertujuan untuk mengetahui pengaruh variable-variabel ekonomi dan variabel sosial terhadap penyerapan tenaga kerja.

\section{Manfaat Penelitian}

Hasil penelitian ini akan memberikan informasi mengenai pengaruh variabelvariabel ekonomi dan variabel sosial terhadap penyerapan tenaga kerja. Dengan mengetahui pengaruh masing-masing variabel maka dapat dilakukan berbagai kebijakan dalam mengatasi pengangguran.

\section{TINJAUAN PUSTAKA}

\section{Tinjauan Penelitian Relevan}

Penelitian yang dilakukan oleh Elnopembri dengan judul "Analisis Faktor-faktor yang Mempengaruhi Penyerapan Tenaga Kerja Industri Kecil Di Kabupaten Tanah Datar Propinsi Sumatera Barat Tahun 1990 - 2004. Faktor-faktor yang mempengaruhi penyerapan tenaga kerja antara lain: upah minimu regional (UMR), tingkat suku bunga kredit investasi Bank Pemerintah Daerah, tingkat suku bunga kredit investasi bank persero pemerintah daerah, dan nilai produksi industri kecil Kabupaten Tanah Datar. Metode analisis yang digunakan adalah analisis regresi berganda yang ditaksir dengan menggunakan metode kuadrat terkecil (Ordinary Least Square, OLS) dalam bentuk semi-log. Hasil analisis regresi menunjukkan bahwa upah minimum regional memiliki pengaruh positif dan signifikan terhadap penyerapan tenaga kerja industri kecil. Tingkat suku bunga kredit investasi Bank Pemerintah Daerah dan Bank Persero Pemerintah di daerah sama-sama memilki pengaruh yang negatif dan signifikan terhadap penyerapan tenaga kerja industri kecil. Nilai produksi industri kecil memilki pengaruh positif dan signifikan terhadap penyerapan tenaga kerja industri kecil.

\section{Tinjauan Teoritis}

1. Hubungan Antara Jumlah Uang Beredar dengan Penyerapan Tenaga Kerja

Secara teoritis, jumlah uang beredar tidak mempengaruhi secara langsung terhadap penyerapan tenaga kerja, tetapi mempengaruhi melalui peningkatan permintaan agregat (agregat demand) dan penawaran agregat (agregat supply). Meningkatkannya jumlah uang beredar akan mempengaruhi peningkatan permintaan agregat. Akibatnya kurva permintaan agregat bergeser ke kanan. Pergeseran kurva permintaaan agregat ke kanan menyebabkan keseimbangan antara permintaan agregat dan penawaran agregat 
berada pada posisi yang lebih tinggi. Penjelasan ini dapat dilihat pada gambar berikut ini.

$\mathrm{H}$

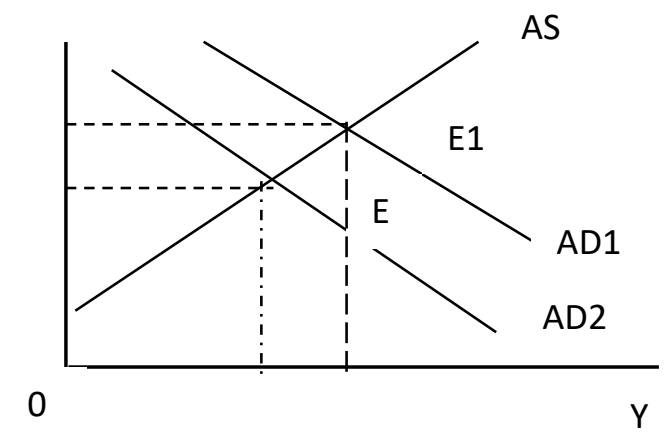

Pada gambar di atas, penawaran agregat meningkat. Pada harga tetap, penawaran agregat naik dari titik keseimbangan $\mathrm{E}$ ke titik keseimbangan $E_{1}$.Untuk memenuhi kenaikan penawaran agregat, maka kapasitas produksi dalam perekonomian di naikkan. Kenaikan kapasitas produksi menuntut kenaikan pemanfaatan fakto-faktor produksi berupa: tanah, modal, dan tenaga kerja. Peningkatan pemanfaatan tenaga kerja dalam perekonomian oleh semua sector menandakan terjadi kenaikan peyerapan tenaga kerja.

Sebaliknya, penurunan jumlah uang beredar akan mengakibatkan terjadi penurunan jumlah permintaan agregat yang berakibat pada penurunan penawaran agregat, dan pada akhirnya menurunkan penyerapan tenaga kerja oleh sector-sektor dalam perekonomian.

2. Hubungan Pengeluaran Pemerintah Dengan Penyerapan Tenaga Kerja

Salah satu komponen APBD adalah belanja daerah.Belanja daerah terdiri dari belanja langsung dan belanja tidak langsung. Belanja daerah berpengaruh secara tidak langsung terhadap permintaan tenaga kerja. Peningkatan APBD akan menyebabkan peningkatan kegiatan ekonomi melalui peningkatan pembelian pemerintah daerah terhadap barang-barang yang dihasilkan oleh produsen. Peningkatan pembelian pemerintah bersama peningkatan pembelian masyarakat untuk konsumsi dan peningkatan pembelian oleh para pengusaha untuk kebutuhan barang modal akan meningkatkan kapasitas produksi. Peningkatan kapasitas produksi meningkatkan penggunaan factor-faktor produksi, salah satunya tenaga kerja. Peningkatan penggunaan tenaga kerja meningkatkan permintaan tenaga kerja, dan peningkatan ini meningkatkan penyerapan tenaga kerja. Hubungan antara pengeluaran pemerintah dengan penyerapan tenaga kerja dapat diperlihatkan melalui gambar berikut.

Pengeluaran pemerintah $\uparrow \rightarrow$ Permintaan agregat $\uparrow \rightarrow$ Penawaran agregat $\uparrow \rightarrow$ Kapasitas produksi $\uparrow \rightarrow$ manfaatan faktorfaktor produksi $\rightarrow$ Penyerapan tenaga kerja个.

3. Hubungan Antara Investasi Dengan

Penyerapan Tenaga Kerja

Secara teoritis, hubungan antara dana investasi dengan tenaga kerja tidak berhubungan secara langsung, tetapi melalui mekanisme hubungan antara dana investasi dengan pengembangan usaha (kapasitas usaha). Peningkatan dana investasi akan meningkatkan pengembangan usaha pada periode berikutnya. Bila dalam perekonomian terjadi peningkatan/pengembangan usaha maka akan terjadi peningkatan pemanfaatan faktor-faktor produksi dalam rangka memenuhi peningkatan kapasitas produksi yang direncanakan. Semakin tinggi pengembangan usaha dalam perekonomian maka perekonomian akan semakin mendekati full employment. Ini berarti terjadi peningkatan penyerapan tenaga kerja dalam perekonomian. Hubungan secara tidak langsung antara dana investasi dengan penyerapan tenaga kerja dapat ditunjukkan pada gambar berikut ini.

Dana investasi $\uparrow \rightarrow$ ekspansi usaha $\uparrow \rightarrow$ pemanfaatan factor-faktor produksi $\uparrow \rightarrow$ penyerapan tenaga kerja $\uparrow$.

4. Hubungan antara Tingkat Upah dan Penyerapan Tenaga Kerja

Permintaan/penyerapan tenaga kerja merupakan fungsi upah riil (W/p). Upah riil adalah upah nominal dibagi harga. Upah riil akan berubah jika upah nominal dan atau harga berubah. Upah riil akan menurun bila upah nominal tetap sementara tingkat harga jual barang makin tinggi. Tingkat upah riil juga akan turun jika harga jual barang tetap, tetapi tingkat upah nominal turun. 
Bila upah riil turun, produsen akan menambah tenaga kerja yang digunakan. Misalnya jika upah nominal turun, tetapi harga jual output tetap, maka produsen mau meningkatkan produksinya dengan meningkatkan kapasitas produksi. Peningkatan kapasitas produksi berarti peningkatan penggunaan faktor produksi tenaga kerja dan faktor produksi lainnya.

Hubungan antara tingkat upah dengan permintaan/penyerapan tenaga kerja berhubungan tidak searah. Hubungan tidak searah ini memberikan arti bahwa jika tingkat upah menurun maka permintaan/penyerapan tenaga kerja meningkat. Sebaliknya, jika tingkat upah meningkat maka permintaan/penyerapan tenaga kerja akan menurun. Hubungan antara tingkat upah dengan penyerapan tenaga kerja dapat diperlihatkan dalam gambar berikut ini.

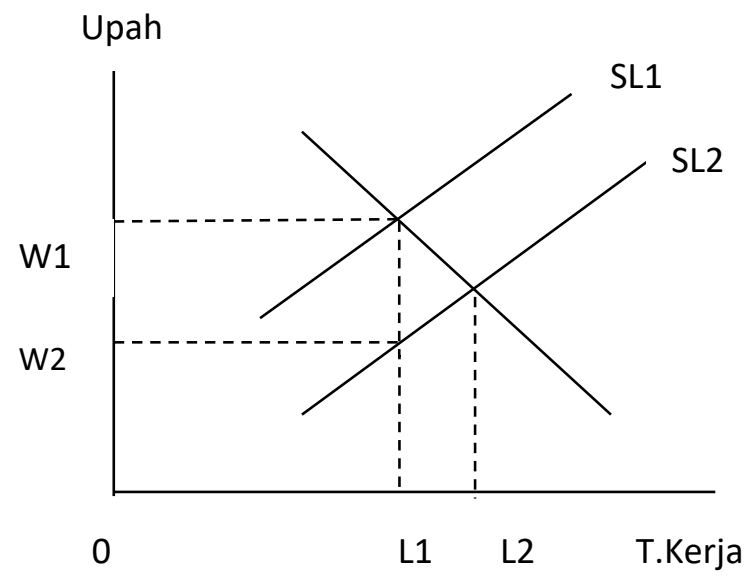

5. Hubungan Antara Tingkat Pendidikan dengan Penyerapan Tenaga Kerja Secara teoritis hubungan antara tingkat pendidikan dengan penyerapan tenaga kerja dapat secara langsung.Permintaan tenaga kerja disamping ditentukan oleh tingkat upah juga ditentukan oleh tingkat pendidikan.Tingkat pendidikan yang dimaksud disini adalah tingkat pendidikan formal dan tingkat keahlian (skill) yang dimiliki oleh penduduk angkatan kerja.

Salah satu factor yang menentukan kemajuan perekonomian suatu Negara/daerah adalah kualitas (pendidikan) sumber daya manusianya.Untuk memajukan perekanomian lebih cepat salah satunya dibutuhkan kualitas (pendidikan) sumber daya manusia yang semakin tinggi.

\section{METODE PENELITIAN}

\section{Jenis Data dan Sumber Data}

Jenis data yang digunakan dalam penelitian ini adalah data sekunder yang diperoleh dari hasil pencatatan yang sistematis berupa data runtut waktu (time series) dan data silang (cross-section) dari tahun 2013-2015 dari seluruh kabupaten dan kota di propinsi NTB. Data penelitian berupa: penyerapan tenaga kerja, jumlah uang beredar, pengeluaran pemerintah daerah kabupaten dan kota, tingkat upah kabupaten/kota (UMK), investasi, dan pendidikan. Sumber data diperoleh dari hasil publikasi Badan Pusat Statistik (BPS), Bank Indonesia Cabang NTB, Biro Keuangan Propinsi NTB, Dinas Ketenagakerjaan Propinsi NTB

\section{Variabel Penelitian}

Variabel adalah konsep yang mempunyai variasi nilai.

\section{Variabel Dependen}

Variabel dependen adalah variabel yang nilainya tergantung pada nilai variabel lain yang merupakan konsekuensi dari perubahan yang terjadi pada variabel bebas (variabel independen). Dalam penelitian ini yang menjadi variabel dependen (variabel terikat) adalah penyerapan tenaga kerja di kabupaten dan kota di propinsi Nusa Tenggara Barat (NTB)

2. Variabel Independen

Variabel independen adalah variabel yang nilainya berpengaruh terhadap variabel lain. Yang menjadi variabel independen adalah:

a. Jumlah uang beredar (JUB)

b. Belanja pemerintah daerah kabupaten dan kota

c. Tingkat upah minimum kabupaten dan kota (UMK)

d. Investasi (penanaman modal dalam negeri, PMDN dan penanaman modal asing (PMA)

e. Pendidikan (jumlah siswa SMA dan SMK kabupaten dan kota di propinsi NTB)

\section{Metode Analisis}

Untuk mengetahui besarnya pengaruh variabel bebas terhadap variabel terikat maka penelitian ini menggunakan regresi linier berganda dengan metode kuadrat terkecil atau Ordinary Least Squere (OLS).Metode ini 
diyakini mempunyai sifat-sifat yang dapat diunggulkan.

Regresi linier berganda adalah regresi linier dimana sebuah variable terikat (variabel Y) dihitung dengan dua atau lebih variable bebas (variabel $\mathrm{X}$ ), secara umum bentuk regresinya adalah sebagai berikut:

$Y=\alpha+b_{1} X_{1}+b_{2} X_{2}+b_{3} X^{3}+b_{4} X_{4}+b_{5} X_{5}$

Fungsi di atas menjelaskan pengertian bahwa peyerapan tenaga kerja dipengaruhi oleh jumlah uang beredar $\left(X_{1}\right)$, belanja pemerintah daerah $\left(X_{2}\right)$, tingkat upah kabupaten/kota $\left(X_{3}\right)$, investasi $\left(X_{4}\right)$, dan Pendidikan $\left(X_{5}\right)$, diasumsikan bahwa variabel lain diluar variabel penelitian tidak berubah.

Keterangan:

$\mathrm{Y}=$ penyerapan tenaga kerja dalam perekonomian

$\alpha=$ kostanta

$\mathrm{X}_{1}=$ jumlah uang beredar (JUB)

$\mathrm{X}_{2}$ = belanja pemerintah daerah

$\mathrm{X}_{3}$ = tingkat upah

\section{HASIL PENELITIAN}

\section{Perkembangan Variabel Penelitian}

Perkembangan penyerapan tenaga kerja paling tinggi terjadi di kabupaten Lombok Utara, yaitu sebesar 34,24\% pada tahun 2014 dan $21,74 \%$ pada tahun 2015 . Selanjutnya, kabupaten Dompu sebesar 14,48 \% dan kabupaten Lombok Barat sebesar 7,28 \% menempati posisi ke dua dan ketiga dalam perkembangan penyerapan tenaga kerja pada tahun 2015. Kabupaten Sumbawa merupakan kabupaten yang menunjukkan perkembangan penyerapan tenaga kerja terendah hanya 0,54 $\%$. Perkembangan jumlah uang beredar tertinggi pada tahun 2014 terjadi di kabupaten Lombok Tengah $(13,22 \%)$ dan perkembangan terendah di kabupaten Bima (6,34 \%). Perkembangan jumlah uang beredar tertinggi pada tahun 2015 terjadi di kota Bima $(33,22 \%)$ dan perkembangan jumlah uang beredar terendah terjadi di kota Mataram $(23,60 \%)$. Secara umum perkembangan jumlah uang beredar diseluruh kabupaten dan kota tahun 2015 berkisar antara $31 \%$ - $33 \%$.

Perkembangan belanja pemerintah daerah tertinggi pada tahun 2014 adalah kabupaten Lombok Barat $(28,77 \%)$, diikuti kabupaten Lombok Timur (22,58 \%) dan kota
Mataram (18,20 \%). Sedangkan perkembangan belanja pemerintah daerah terendah adalah kabupaten Sumbawa Barat $(4,44 \%)$ dan kabupaten Lombok Tengah $(7,40$ \%). Pada tahun 2015 adalah kabupaten Sumbawa $(36,47 \%)$ dan kabupaten Lombok Timur (31,26 \%). Perkembangan belanja pemerintah daerah terendah adalah kabupaten Lombok Tengah (12,13 \%) dan kota Mataram (13,82 \%). Secara umum, perkembangan belanja pemerintah daerah kabupaten dan kota di propinsi NTB tahun 2015 berkisar antara $17 \%-36 \%$.

Perkembangan tingkat upah minimun kabupaten/kota tertinggi adalah kota Mataram (23,02 \%), kemudian diikuti oleh kabupaten Lombok Timur (22,82 \%), Lombomk Barat (22,45 \%), dan Dompu $(21,60$ $\%)$. Perkembangan terendah kabupaten Lombok Tengah $(14,17 \%)$ dan kabupaten Sumbawa $(16,72 \%)$.

Perkembangan investasi tertinggi pada tahun 2014 adalah di Kabupaten Lombok Utara sebesar 45,72\%. Kemudian Lombok Timur sebesar 44,97\% dan Sumbawa Barat sebesar 27,30\%. Pada tahun 2015 perkembangan investasi tertinggi di Kabupaten Dompu sebesar $21,60 \%$ dan dikikuti oleh Kabupaten Lombok Utara sebesar 18,19\% dan Kabupaten Lombok Timur sebesar 14,24\%. Perkembangan investasi terendah adalah kota Mataram dan kabupaten Lombok Tengah. Sedangkan pada tahun 2015, kabupaten Bima, kota Mataram, dan kabupaten Lombok Tengah.

4.2. Hasil Penelitian

Jumlah uang beredar tidak memberikan pengaruh nyata dengan nilai probabilita 0,1440 lebih besar dari $\alpha 5 \%$ (atau $>0,05)$ dan angka koefisien regresi sebesar 0,009735 . Belanja pemerintah daerah memberi pengaruh nyata dengan nilai probabilita 0,0181 kurang dari $\alpha 5 \%$ (atau < $0,05)$ dan angka koefisien regresi 0,164227. Tingkat upah minimum kabupaten/kota memberi pegaruh nyata dengan nilai probabilita 0,0239 kurang dari $\alpha 5 \%$ (atau < $0,05)$ dan angka koefisien regeresi sebesar 0,196387 . Investasi tidak memberikan pengaruh nyata dengan nilai probabilita 0,4154 lebih besar dari a $5 \%$ (atau > 0,05) dan angka koefisien regresi sebesar 0,042074. 
Pendidikan memberi pengaruh nyata terhadap penyerapan tenaga kerja dengan nilai probalita 0,0094 kurang dari $\alpha 5 \%$ (atau $<0,05)$ dan angka koefisein regresi sebesar 5,377819 .

Jumlah uang beredar, belanja pemerintah daerah, tingkat upah minimum kabupaten/kota, investasi dan pendidikan secara bersama-sama berpengaruh secara signifikan terhadap penyerapan tenaga kerja, dimana F-statistik lebih besar dari $\mathrm{F}$ tabel, dengan koefisien determinasi (R-squared) sebesar 0,929550, yang mengindikasikan 92,95\% penyerapan tenaga kerja ditentukan oleh variabel independen.

\section{KESIMPULAN DAN SARAN}

\section{Kesimpulan}

1. Jumlah uang beredar berpengaruh terhadap penyerapan tenaga kerja, tetapi pengaruhnya tidak signifikan

2. Belanja pemerintah daerah kabupaten / kota berpengaruh secara signifikan terhadap penyerapan tenaga kerja.

3. Tingkat upah minimjum kabupaten / kota berpengaruh secara signifikan terhadap penyerapan tenaga kerja.
4. Investasi berpengaruh terhadap penyerapan tenaga kerja, tetapi pengaruhnya tidak signifikan

5. Pendidikan berpengaruh secara signifikan terhadap penyerapan tenaga kerja.

\section{Saran}

1. Pemerintah daerah kabupaten dan kota harus terus berupaya secara maksimal untuk meningkatkan pendapatan daerah dengan melakukan intensifikasi dan ekstensifikasi sumber-sumber pendapatan daerah. Pendapatan daerah yang meningkat secara otomatis akan meningkatkan pengeluaran / belanja daerah dan dampak akhirnya akan meningkatkan penyerapan tenaga kerja.

2. Peningkatan kuantitas dan kualitas pendidikan harus terus ditingkatkan oleh pemerintah daerah kabupaten dan kota melalui peningkatan anggaran untuk pendidikan.

3. Peningkatan investasi di daerah baik PMDN maupun PMA sangat perlu ditingkatkan terus agar tenaga kerja dapat terserap lebih banyak dari tahun ke tahu

\section{DAFTAR PUSTAKA}

Badan Pusat Statistik. Propinsi Nusa Tenggara Barat Dalam Angka 2014 . Propinsi Nusa Tenggara Barat Dalam Angka 2015 . Propinsi Nusa Tenggara Barat Dalam Angka 2016

Dernburg, Thomas F. dk, 1982.Ekonomi Makro: Perhitungan, Analisis, dan Kebijaksanaa Perekonomian. Penerbit Erlangga, Jakarta Pusat.

Hasibuan, Melayu SP, 1987. Ekonomi Pembangunan dan Perekonomian Indonesia. Bandung: CV. Arnico.

Narbuko, H. Abu Achmadi, 2002. Metodologi Penelitian. Jakarta: Bumi Aksara.

Nazir, Moh., 1999. Metode Penelitian. Jakarta: Ghalia Indonesia.

Rahardja, Prathama, dk, 2008. Pengantar Ilmu Ekonomi (Makroekonomi dan Mikroekonomi). Penerbit: Lembaga Penerbit Fakultas Ekonomi Indonesia

Todaro, Michael. P. 1998. Pembangunan Ekonomi di Dunia Ketiga. Edisi Ketujuh. Jakarta: Erlangga.

Widodo, Suseno Triyanto, 1991. Indikator Ekonomi: Dasar Perhitungan Ekonomi Indonesia. Jakarta: Ghalia Indonesia. 